\title{
Comparisonal Analysis Of Incremental Conductance And Perturb And Observe Methods As MPPT Algorithm In Photovoltaic System
}

\author{
Taufik Alfajri Zulhelmi \\ Department Of Electrical Engineering, University Of North Sumatra, Jl. Dr. Mansur No. 9 Padang Bulan, Kec. \\ Medan Baru, Kota Medan 20222
}

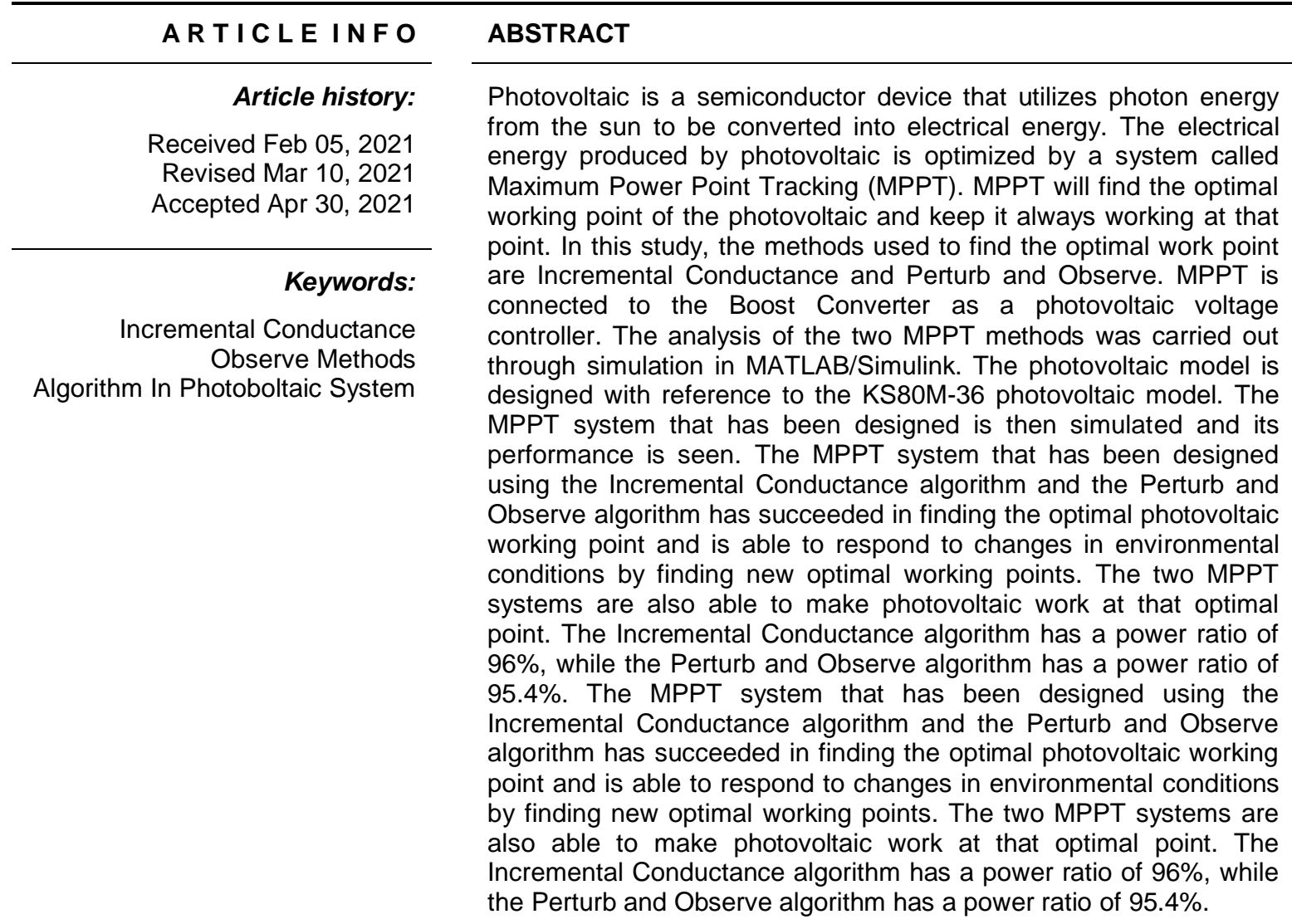

This is an open access article under the CC BY-NC license.

\section{Corresponding Author:}

Taufik Alfajri Zulhelmi ,

Department Of Electrical Engineering,

University Of North Sumatra,

Jl. Dr. Mansur No. 9 Padang Bulan, Kec. Medan Baru, Kota Medan 2022.

Email : taufikalfajri@gmail.com

\section{INTRODUCTION}

Solar energy is a natural resource that has a huge influence on the development of life on Earth. Its inexhaustible existence is the reason why solar energy is said to be a renewable energy source. 
One application of the use of solar energy is photovoltaic, which is a device that converts photon energy into electrical energy. Photovoltaic offers many advantages including, does not require fuel oil, low maintenance costs, and does not produce noise. Photovoltaic has been widely used as a solution to various common problems, such as helping street lighting, electric vehicles, smart houses, etc.

The main problem in the use of photovoltaic is the low electrical energy produced, especially at low radiation conditions and fluctuating temperatures. In various changes in temperature and radiation conditions, there is a point where solar cells will produce the highest energy with maximum efficiency. This point is called MPP (Maximum Power Point). The location of the MPP is unknown, but can be found by calculating or applying a tracking algorithm (Maximum Power Point Tracking) so that the photovoltaic generated power is always at the MPP in various environmental conditions.

Along with the large community demand for electrical energy, various solutions are sought to cover the shortcomings of solar cells. So that many MPPT algorithms have been found and researched, in previous studies research has been carried out using various methods such as Perturb and Observe, Incremental Conductance, Dynamic Approach, Temperature Methods, Artificial Neural Network, Fuzzy Logic Method, etc.

\section{RESEARCH METHOD}

The research steps are as follows:

a. Data collection

The data for photovoltaic is taken from the KS80M-36 datasheet. The value of radiation and temperature as input to the photovoltaic is made to vary.

b. Making Photovoltaic Models, MPPT, and Boost converters

After the data is obtained, then make a photovoltaic model based on the datasheet used, MPPT with Perturb and Observe algorithm, MPPT with Incremental Conductance algorithm, and Boost converter.

c. Running Simulation

The simulation is run by giving radiation and temperature input to the photovoltaic module. Simulations are carried out on a system designed with the Perturb and Observe algorithm and the Incremental Conductance algorithm. From this simulation we can see the output values of the two systems and compare and analyze them.

d. Showing Results.

In this study, the authors want to see the performance and differences of a photovoltaic system using MPPT with Perturb and Observe algorithms and Incremental Conductance.

\section{RESULTS AND DISCUSSIONS}

The photovoltaic system has been built and tested in chapter 3 to have the appropriate characteristics with the reference photovoltaic model. The Incremental Conductance, Perturb and Observe, and Boost Converter algorithms connected to MPPT have also been designed in chapter 3. The next discussion is the analysis and simulation of the system that has been designed and built in chapter 3 .

\subsection{System Simulation at Fixed Environmental Conditions}

Figure 1 shows a simulation block diagram of the MPPT system that has been built. Thus, the MPPT system can be simulated on SIMULINK-MATLAB. In this section, the system will be simulated under standard measurement conditions, namely radiation of $1000 \mathrm{~W} / \mathrm{m} 2$ and photovoltaic temperature of $25^{\circ} \mathrm{C}$. Figure 3.6 shows the characteristic curve of photovoltaic when the radiation condition is $1000 \mathrm{~W} / \mathrm{m} 2$ and the temperature is $25^{\circ} \mathrm{C}$. Where the maximum power that can be achieved by photovoltaic is $80 \mathrm{Watt}$.

\section{a. Simulation Without MPPT}




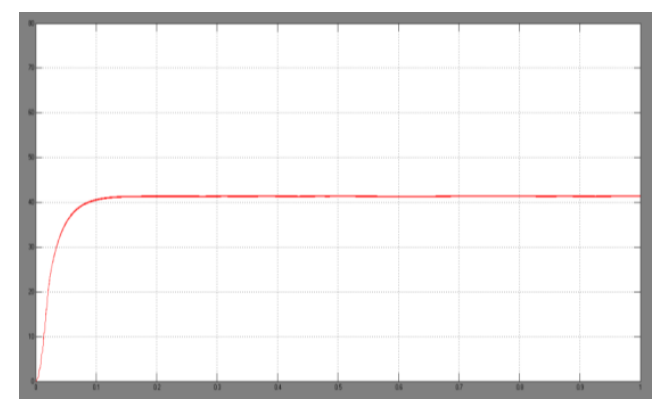

Figure 1. Photovoltaic Power Curve Without Using MPPT

The photovoltaic power curve, in this state the photovoltaic is capable of producing 76.49 Watts of power. This value is the steady state condition of the $\operatorname{Ppv}(\mathrm{t})$ curve. When compared with the maximum power that can be produced by photovoltaic in Figure 3.6, which is 80 Watts. It can be seen that the power generated by the system with this algorithm is able to approach the maximum photovoltaic power value. This value is not suitable because Ppv is isolated, so the Ppv data has a spread of the average value. The rounding done in the calculation also makes the imbalance appear. From the figure, it can also be seen that the oscillation occurs when the MPPT system has found its optimal working point.

\subsection{System Simulation In Changing Environmental Conditions}

In this section, the MPPT system will be simulated under changing environmental conditions. In order to be able to carry out in-depth analysis and see the performance of this algorithm, two different simulations were carried out. In the first simulation, the radiation conditions varied while the temperature was kept constant. In the second simulation, the temperature conditions varied while the radiation was kept constant.

\section{a. Radiation Change}

In this simulation, the radiation value will vary, either increasing or decreasing. Table 1 shows the adjustment of changes in light conditions in the simulation to be carried out. The temperature is kept constant at $25^{\circ} \mathrm{C}$.

Table 1. Variation of Radiation Conditions

\begin{tabular}{ccc}
\hline NO & Simulation Time $(s)$ & Radiation $(\mathrm{W} / \mathrm{m} 2)$ \\
\hline 1 & $0 \mathrm{t}<1$ & 800 \\
2 & $1 \mathrm{t}<2$ & 500 \\
3 & $2 \mathrm{t} 3$ & 1000 \\
\hline
\end{tabular}

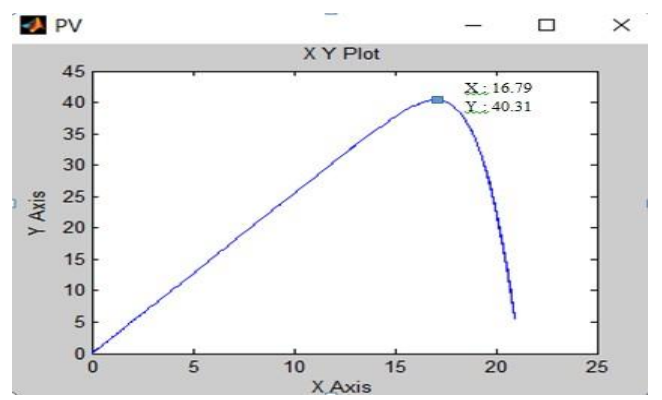

Figure 2. PV Photovoltaic Characteristics Curve At $500 \mathrm{~W} / \mathrm{m} 2$. Radiation 


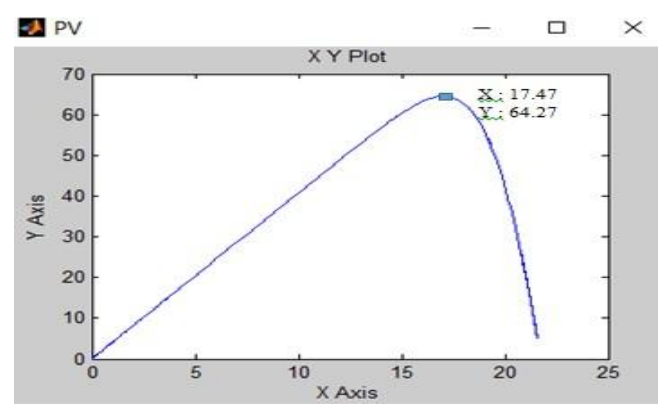

Figure 3. PV Photovoltaic Characteristics Curve At $800 \mathrm{~W} / \mathrm{m} 2$. Radiation

Figures 2 and 3 show that at radiation of $500 \mathrm{~W} / \mathrm{m} 2$ the maximum power that can be achieved by photovoltaic is 40.31 Watt, while at radiation of $800 \mathrm{~W} / \mathrm{m} 2$ the maximum power that can be achieved by photovoltaic is 64.27 watts. That way, the value that must be achieved by the MPPT is the maximum power, and is constant in that area.

\section{b. Simulation Without MPPT}

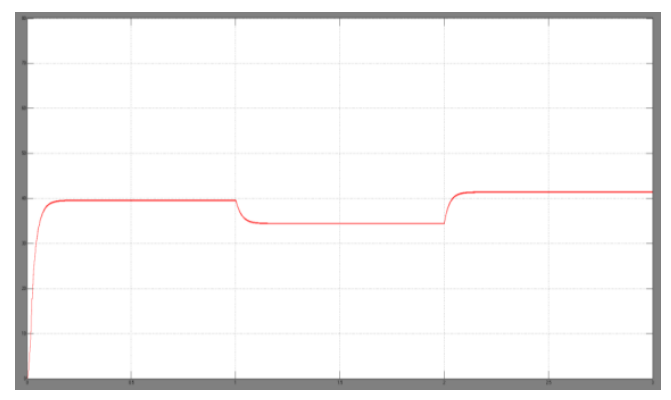

Figure 4. Photovoltaic Power Curve Without MPPT at Varied Radiation

Figure 4 shows that the power generated by photovoltaic without using MPPT under varying radiation conditions. When the radiation is $800 \mathrm{~W} / \mathrm{m} 2$, the power generated by the photovoltaic is 39.6 Watts. When the radiation drops to $500 \mathrm{~W} / \mathrm{m} 2$, the power generated is 34.44 Watts. And when the radiation rises to $1000 \mathrm{~W} / \mathrm{m} 2$ the power increases to 41.53 Watts.

\subsection{Incremental Conductance Algorithm}

In this experiment, a photovoltaic system that has been connected to the Incremental Conductance algorithm will be simulated with varying radiation conditions and constant temperature. Where will be tested with radiation that varies within 3 seconds.

Under varying radiation conditions, MPPT will track the maximum power that the photovoltaic can produce under those conditions. When the radiation is $800 \mathrm{~W} / \mathrm{m} 2$, the maximum power generated by the photovoltaic is 61.53 Watts and will be constant in that area. When the radiation drops to $500 \mathrm{~W} / \mathrm{m} 2$, the power generated is 38.78 Watts. And when the radiation rises to 1000 $\mathrm{W} / \mathrm{m} 2$, the power also increases to 76.49 Watts.

\subsection{Perturb and Observe Algorithm}

In this experiment, a photovoltaic system that has been connected to the perturb and observe algorithm will be simulated with varying radiation conditions and constant temperature. Where will be tested with radiation that varies within 3 seconds.

That under varying radiation conditions, MPPT will track the maximum power that can be generated by photovoltaic under these conditions. When the radiation is $800 \mathrm{~W} / \mathrm{m} 2$, the maximum power generated by the photovoltaic is 61.19 Watts and will be constant in that area. When the 
radiation drops to $500 \mathrm{~W} / \mathrm{m} 2$, the power generated is 38.7 Watts. And when the radiation rises to $1000 \mathrm{~W} / \mathrm{m} 2$, the power also increases to 76.14 Watts.

\subsection{Photovoltaic Power Comparison}

The following is an image of the power against time generated by photovoltaic using an algorithm and without an algorithm.

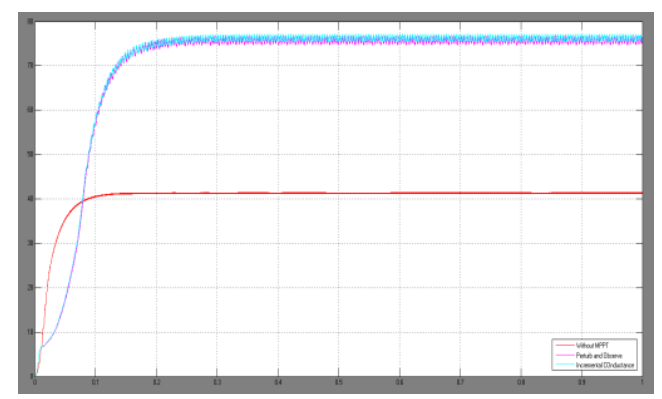

Figure 5. Power Curve Against Time at 1000W/m2 Radiation Conditions with 3 Methods

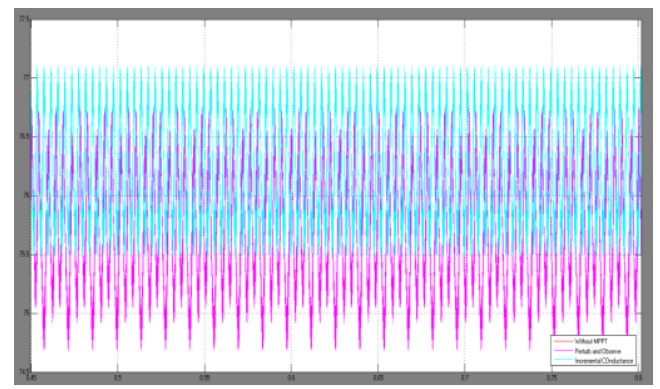

Figure 6. Power Curve Against Time at 1000W/m2 Radiation Conditions with Incremental Conductance and Perturb and Observe Algorithms

From Figures 5 and 6 it can be seen that the power generated by photovoltaic with MPPT using the Incremental Conductance algorithm produces fewer fluctuations than Perturb and Observe. In determining the maximum point the fastest is also obtained by MPPT with the Incremental Conductance algorithm.

After testing the Incremental Conductance and Perturb and Observe algorithms, the data collected is shown in the following table:

Table 2 .Comparison of Photovoltaic Power in Incremental Conductance and Perturb and Observe Algorithms

\begin{tabular}{cccccccc}
\hline Radiation & $\begin{array}{c}\text { Tempera } \\
\text { ture } \\
\left({ }^{\circ} \mathrm{C}\right)\end{array}$ & $\begin{array}{c}\text { PMPP } \\
\text { Theoretical }\end{array}$ & $\begin{array}{c}\text { Without } \\
\text { MPPT }\end{array}$ & $\begin{array}{c}\text { P\&O } \\
\text { (Watt) }\end{array}$ & $\begin{array}{c}\text { Efficiency } \\
(\%)\end{array}$ & $\begin{array}{c}\text { InC } \\
(\text { Watt })\end{array}$ & $\begin{array}{c}\text { Efficiency } \\
(\%)\end{array}$ \\
\hline \multirow{2}{*}{500} & 25 & 40.31 & 34.44 & 38,70 & 96.0 & 38.78 & 96.3 \\
& 27 & 39.95 & 33.98 & 38.30 & 95.9 & 38.42 & 96.3 \\
600 & 25 & 48.51 & 36.77 & 46.51 & 95.9 & 46.52 & 95.9 \\
& 27 & 47.95 & 36.26 & 45.97 & 95.9 & 46.17 & 96.3 \\
& 25 & 64.27 & 39.60 & 61.19 & 95.2 & 61.53 & 95.7 \\
\hline
\end{tabular}




\begin{tabular}{llllllll}
\hline & 27 & 63.50 & 39.07 & 60.59 & 95.4 & 60.95 & 96.0 \\
\multirow{2}{*}{1000} & 25 & 80.00 & 41.53 & 76.14 & 95.2 & 76.49 & 95.6 \\
& 27 & 79.50 & 40.88 & 74.63 & 93.9 & 75,80 & 95.3 \\
\hline
\end{tabular}

From table 2, the power generated by photovoltaic using both Incremental Conductance and Perturb and Observe algorithms is almost the same, where the difference is approximately 0.5 Watt. So, it can be said that both algorithms are able to find the optimum point of a photovoltaic. Overall, the algorithm that has a higher efficiency is Incremental Conductance. But the simplest algorithm to design is Perturb and Observe.

\section{CONCLUSION}

At a radiation condition of $1000 \mathrm{~W} / \mathrm{m} 2$ and a temperature of $25^{\circ} \mathrm{C}$, the maximum power that can be achieved by the KS80M-36 type photovoltaic is 80 Watt. MPPT with Incremental Conductance algorithm is capable of producing 76.49 Watts of power while MPPT with Perturb and Observe algorithms is 76.14 Watts.

The Incremental Conductance and Perturb and Observe algorithms as MPPT algorithms are proven to be able to find the optimal working point of a photovoltaic in varying radiation and temperature conditions, even MPPT is also able to respond quickly and find new optimal points when radiation conditions change rapidly. When the radiation conditions change from $500 \mathrm{~W} / \mathrm{m} 2$ to $1000 \mathrm{~W} / \mathrm{m} 2$, MPPT with the Incremental Conductance algorithm is able to change the power from 38.78 Watts to 76.49 Watts. While the Perturb and Observe algorithm changes the power from 38.7 Watts to 76.14 Watts.

The MPPT system with the Incremental Conductance algorithm has a power efficiency of $96 \%$ while the MPPT system with the Perturb and Observe algorithm has a power efficiency of $95.4 \%$.

\section{REFERENCES}

Hegedus, S., \& Luque, A. (2003). Handbook of Photovoltaic Science and Engineering. West Sussex: John Wiley \& Sons.

Tsai, H.-L., Tu, C.-S., \& Su, Y.-J. (2008). Development of Generalized Photovoltaic Model Using MATLAB/SIMULINK. WCECS.

Babgei A. F., 2012, Rancang Bangun Maximum Power Point Tracker (MPPT) pada Panel Surya Dengan menggunakan metode Fuzzy, Institut Teknologi Sepuluh November, Surabaya.

Widodo, Rusminto T., Rugianto, Asmuniv, Sejati, Purnomo, "Maximum Power Point Tracker Sel Surya Menggunakan Algoritma Perturb And Observe", Politeknik Elektronika Negeri Surabaya-ITS, Surabaya, Indonesia.

Schmid, J., \& Schmidt, H. (2003). Power Conditioning for Photovoltaic Power Systems. In Handbook of Photovoltaic Science and Engineering (pp. 863- 903).John Wiley \& Sons, LTD.

Esram, T., \& Chapman, P. L. (2007). Comparison of Photovoltaic Array Maximum Power Point Tracking Techniques. Energy Conversion, IEEE Transactions on , 22 (2), $439-449$.

Hart, D. W. (1997). Introduction to Power Electronics. New Jersey: Prentics-Hall.

Athimulam Kalirasu, Subharensu Sekar Dash, "Simulation of Closed Loop Controlled Boost Converter for Solar Installation", Serbian Journal of Electrical Engineering Vol. 7, No. 1, May 2010, 121-130.

Lin, L. K. (2009). A Hybrid Wind/Solar Energy Converter. SIM University.

Ananduta, Wayan Wicak (2011). Simulasi dan Analisis Sistem Maximum Power Point Tracker Berbasis Rangkaian Boost Converter. UI, Depok, Indonesia. 